\title{
RANCANG BANGUN ROBOT PEMOTONG RUMPUT OTOMATIS MENGGUNAKAN WIRELESS KONTROLER MODUL ESP32-CAM BERBASIS INTERNET of THINGS (IoT)
}

\author{
Azis Isrofi ${ }^{1)}$ Shoffin Nahwa Utama $^{2)}$ Oddy Virgantara Putra ${ }^{3)}$ \\ 1,2,3 Fakultas Sains dan Teknologi - Program Studi Teknik Informatika - Universitas Darussalam Gontor \\ 1,2,3 Jl. Raya Siman No.Km. 6, Dusun I, Ponorogo 63471 \\ Email: ${ }^{1}$ azisisrofi90@unida.gontor.ac.id, ${ }^{2}$ shoffin@unida.gontor.ac.id, ${ }^{3}$ oddy@unida.gontor.ac.id
}

\begin{abstract}
Today's robotics technology has experienced rapid development. The development of robotics technology can help human work. One human job that can be helped by robots is cutting grass. In a study conducted by Fajar Rinto Hadi Putra, Tri Kuntoro Priyambodo and Jecky Yusakh Akay about robots can be controlled at an optimal distance of no more than 7.2 meters and the speed of the lawn mower can not be controlled, so that the battery becomes wasteful. The purpose of this research is to design a prototype of a grass cutter robot using an IoT-based wireless controller ESP32CAM module and a lawn mower actuator can be controlled via a web browser. Testing is done by using ESP32-CAM as a microcontroller, OV2640 camera module as monitoring the area of grass to be cut, ESP32 wifi module as a connection between the robot and the robot controller device, and brushless motor as a mover blade. The use of this brushless motor can be controlled using the ESC30A speed module, so that it can save battery power usage. The results of the robot controller can be accessed using the IP address obtained from the access point connected to the ESP32 CAM module. IP address can be accessed through a web browser on a laptop or smartphone so that the robot can be controlled remotely. Based on the test results it can be concluded that the lawn mower robot can cut grass with a wifi controller with a control distance of 50 meters. The use of a brushless motor on the blade of a lawn mower can control the speed of rotation of the actuator, so as to save battery usage by $0.16 \mathrm{~V}$ per minute with maximum speed.
\end{abstract}

Keyword: Grass Cutting Robot, ESP32-CAM, OV2640 camera module, Brushless, IoT

\begin{abstract}
Abstrak
Teknologi robotika dewasa ini telah mengalami perkembangan yang pesat. Perkembangan teknologi robotika ini dapat membantu pekerjaan manusia. Salah satu pekerjaan manusia yang dapat dibantu oleh robot adalah memotong rumput. Pada penelitian yang dilakukan oleh Fajar Rinto Hadi Putra, Tri Kuntoro Priyambodo dan Jecky Yusakh Akay tentang robot dapat dikontrol pada jarak optimal tidak lebih dari 7,2 meter dan kecepatan mata pisau pemotong rumput tidak dapat dikontrol, sehingga baterai menjadi boros. Tujuan dari penelitian ini ialah merancang sebuah prototype robot pemotong rumput menggunakan wireless kontroler modul ESP32-CAM berbasis IoT dan actuator pemotong rumput dapat dikontrol melalui web browser. Pengujian dilakukan dengan menggunakan ESP32-CAM sebagai mikrokontroler, modul kamera OV2640 sebagai monitoring area rumput yang akan dipotong, modul wifi ESP32 sebagai koneksi antara robot dengan perangkat kontroler robot, dan motor brushless sebagai penggerak mata pisau pemotong rumput. Penggunaan motor brushless ini dapat dikontrol kecepatannya menggunakan modul ESC30A, sehingga dapat menghemat penggunaan daya baterai. Hasil kontroler robot dapat diakses dengan menggunakan ip address yang didapatkan dari acces point yang terhubung pada modul ESP32 CAM. Ip address dapat diakses melalui web browser pada perangkat laptop atau smartphone sehingga robot dapat dikontrol dengan jarak jauh. Berdasarkan hasil pengujian dapat disimpulkan bahwa robot pemotong rumput dapat memotong rumput dengan kontroler wifi dengan jarak kontrol 50 meter. Penggunaan motor brushless pada mata pisau pemotong rumput dapat kontrol kecepatan putaran aktuatornya, sehingga dapat menghemat penggunaan baterai sebesar $0,16 \mathrm{~V}$ permenit dengan kecepatan maximal.
\end{abstract}

Kata Kunci: Robot Pemotong Rumput, ESP32-CAM, Modul kamera OV2640, Brushless,IoT

\section{Pendahuluan}

Teknologi robotika dewasa ini telah mengalami perkembangan yang pesat, yang mana perkembangan dari teknologi robotika berdampak dalam kehidupan manusia. Tujuan dari perkembangan teknologi robotika berkaitan erat dengan adanya kebutuhan alat yang dapat membantu manusia dalam menyelesaikan pekerjaan. Salah satu pekerjaan manusia yang dapat diselesaikan oleh robot adalah memotong rumput. Fungsi dari robot ini adalah memotong rumput secara otomatis, yang mana berguna 
untuk mempermudah pekerjaan dan menghemat waktu dalam memotong rumput.

Penelitian yang dilakukan oleh Fajar Rinto Hadi Putra, dan Tri Kuntoro Priyambodo tentang Purwarupa Pengendalian Jarak Jauh Pada Mobile Robot Berbasis Web Melalui Jaringan Wireless TCP/IP[1]. Purwarupa mobil robot menggunakan sistem gerak menyerupai tank, yang dilengkapi sebuah kamera untuk keperluan surveillance ini, pengguna menggunakan webcam. Karena purwarupa mobile robot ini dapat dikendalikan jarak jauh menggunakan aplikasi berbasis web dari komputer host melalui media jaringan wireless TCP/IP, ditunjukan untuk keperluan panginderaan jarak jauh di lingkungan yang berbahaya bagi keselamatan manusia. Kominikasi yang dilakukan menggunakan sebuah perangkat wireless untuk dua arah mengirim dan menerima data. Berdasarkan hasil pengujian dan Analisa percobaan mobile robot yang telah dilakukan, jarak optimal pengendalian dari mobile robot tidak lebih dari 7,2 meter, dengan tanpa adanya penghalang (line of sight) antara pengendali dengan mobile robot.

Selain itu, penelitian yang dilakukan Jecky Yusakh Akay dan Janny O[2] tentang Rancangan Alat Pemotong Rumput Otomatis merupakan penerapan sistem otomasi. Dalam sistem otomasi digunakan module motor driver L289N untuk mengendalikan roda robot secara otomatis. Sistem otomasi ini menggunakan mikrokontroler dengan tipe AVR ATMega16 sebagai alat pengontrol, dan 7 buah sensor limit switch untuk mendeteksi halangan. Sumber tenaga berasal dari baterai jenis Lippo dengan arus 2200mAh dan tegangan 11.1 Volt, yang dialirkan ke mikrokontroler, motor driver dan sensor. Penggunaan motor DC pada pisau pemotong kurang efisien. Kecepatan putaran pisau pemotong rumput yang dihasilkan dari motor DC tergantung dari sumber daya, dan penggunaan motor DC tidak dapat dikontrol kecepatan putaranya sehingga mempengaruhi penggunaan baterai yang boros.

Oleh karena itu, penelitian ini bertujuan untuk merancang sebuah prototype alat pemotong rumput otomatis dengan menggunakan Mikrokontroler yang berjudul "RANCANG BANGUN ROBOT PEMOTONG RUMPUT OTOMATIS MENGGUNAKAN WIRELESS KONTROLER MODUL ESP32-CAM BERBASIS INTERNET of THINGS (IoT) " yang mana robot pemotong rumput ini dapat membantu manusia dalam meringankan pekerjaannya dan manusia bisa langsung memotong rumput dengan kontrol wireless.

\section{Kajian Teori}

\subsection{Penelitian Terdahulu}

Pada penelitain yang berjudul Rancang Bangun Alat Pemotong Rumput Otomatis adalah penggunaan driver motor L298N sebagai pengendali kecepatan motor DC pada roda robot. Jenis supply tegangan yang digunakan berjenis Lippo dengan arus sebesar 2200mAh, dengan keluaran tegangan 11.1volt. Penggunaan sensor limit switch berguna untuk mendeteksi halangan pergerakan robot.[2]
Sedangkan pada penelitian dengan judul Perancangan Model Alat Pemotong Rumput Otomatis Berbasis Mikrokontroler AT89C51 adalah sistem minimum dengan menggunakan mikrokontroler jenis AT89C51. Mikrokontroler AT89C51 berfungsi sebagai sistem pembaca program pada tombol keypad. Route perjalanan robot pemotong rumput berbentuk zig-zag, dengan ketepatan sudut belok kanan sebesar 1800 adalah $95,7 \%$ dan ketepatan sudut kiri $98 \%$. Sudut yang dicapai ketika melakukan gerak belok tidak konstan 1800.[3]

Penelitian dengan judul Prototype Robot Pemotong Rumput Berbasis Raspberry Pi B+ Menggunakan Web Browser adalah robot cerdas pemotong rumput berbasis raspberry $\mathrm{Pi} \mathrm{B}+$ merupakan sistem robotik yang bertujuan mengendalikan 2 buah motor Driver 1289N yang berguna untuk menjalankan gear box roda robot dan dinamo pemotong rumput pada alat pemotong rumput tanpa awak. Robot cerdas pemotong rumput dapat dengan langsung melakukan pemotongan rumput dengan dikendalikan web browser.[4]

Penelitian dengan judul purwarupa Pengendalian Jarak Mobile Robot Berbasis Web Melalui Jaringan Wireless TCP/IP adalah rancangan sebuah purwarupa mobile robot yang dapat dikendalikan dari jarak jauh, dengan berbasis web melalui jaringan TCP/IP. Purwarupa mobil robot menggunakan sistem gerak menyerupai tank, yang dilengkapi sebuah kamera untuk keperluan surveillance ini, pengguna menggunakan webcam. Berdasarkan hasil hasil pengujian dan Analisa percobaan mobile robot yang telah dilakukan, jarak optimal pengendalian dari mobile robot tidak lebih dari 7,2 meter, dengan tanpa adanya penghalang (line of sight) antara pengendali dengan mobile robot.[1]

Pada penelitian yang berjudul Rancang Bangun Robot Prmotong Rumput Otomatis Berbasis Arduino Menggunakan Wireless Kontroler Dan Solar Cell adalah media komunikasi nirkabel yang digunakan adalah modul Bluetooth HC-06 yang berfungsi sebagai media pengendali robot pemotong rumput. Jarak yang dijangkau robot pemotong rumput agar dapat dikendalikan dengan baik antara 1 meter hingga 10 meter.[5]

Penelitian dengan judul Perancangan Alat Pemotong Rumput Otomatis Berbasis Arduino Uno Memakai Joystick adalah Joystick berfungsi sebagai sistem kendali yang dapat memonitoring robot melalui perangkat joystick. Penggunaan joystick yang dapat mengendalikan robot dengan baik yang berjarak 10 meter.[6]

\subsection{Landasan Teori}

\subsubsection{Robotika}

Kata "robot" diambil dari bahasa Ceko (Chech), yang memiliki arti "pekerja" (worker). Robot merupakan suatu perangkat mekanik yang mampu menjalankan tugas-tugas fisik, baik di bawah kendali dan pengawasan manusia, ataupun yang dijalankan dengan serangkaian program yang telah didefinisikan terlebih dahulu atau kecerdasan buatan (artificial intelligence).[2]

\subsubsection{ESP32-CAM}

Modul Al-Thinker ESP32-CAM dilengkapi dengan chip ESP32-S, kamera OV2640 berukuran sangat kecil dan slot kartu micro SD. Slot kartu micro SD dapat 
digunakan untuk menyimpan gambar yang diambil dari kamera atau untuk menyimpan file. Modul ESP32-CAM ini dapat digunakan secara luas di berbagai aplikasi IoT.[7] ESP32-CAM yang digunakan dalam penelitian ini disajikan dalam Gambar 1.

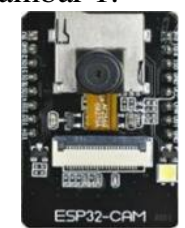

Gambar 1. Modul Mikrokontroler ESP32-

\section{CAM 2.2.3 Internet of Things}

Internet of Things (IoT) adalah struktur di mana objek orang disediakan dengan identitas ekslusif dan kemampuan untuk pindah data melalui jaringan tanpa memerlukan dua arah antara manusia ke manusia yaitu sumber ke tujuan atau interaksi manusia ke komputer. Internet of Things merupakan perkembangan keilmuan yang sangat menjajikan untuk mengoptimalkan kehidupan berdasarkan sensor cerdas dan peralatan pinter yang bekerjasama melalui jaringan internet.[8]

\subsubsection{Motor Driver L289N}

Driver motor L298N merupakan driver motor yang paling populer digunakan untuk mengontrol kecepatan dan arah pergerakan motor terutama pada robot line follower / line tracer.[9] Motor driver L298N yang digunakan dalam penelitian ini disajikan dalam Gambar 2.

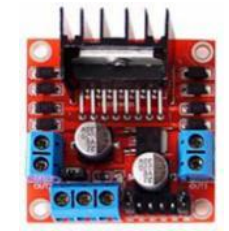

Gambar 2. Modul Motor driver

\section{L298N 2.2.5 Motor Brushless DC}

Motor Brushless DC (BLDC) adalah jenis motor DC yang tidak memiliki sikat. Dengan dihilangkannya bagian sikat dan komutator, motor ini memiliki kelebihan antara lain adalah peningkatan pada efisiensi, pengurangan kebisingan yang ditimbulkan saat berputar, perawatan yang lebih murah, serta dapat berputar dengan kecepatan tinggi karena berkurangnya gesekan dengan sikat.[10] Brushless motor yang digunakan pada penelitian ini disajikan dalam Gambar 3.

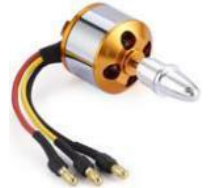

Gambar 3. Motor Brushless

\section{2.2.6 ESC 30A}

ESC (Electronic Speed Controller) adalah modul minimum sistem rangkaian elektronika yang didesain untuk menyuplai arus pada motor untuk mengatur putaran motor yang disesuaikan dengan kebutuhan dari motor tersebut.[11] Modul ESC 30A yang digunakan dalam penelitian ini disajikan pada Gambar 4 .

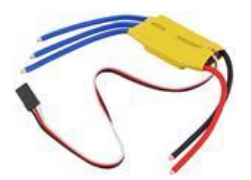

Gambar 4. Modul ESC

30A 2.2.7 Motor DC

Motor Listrik DC atau Motor DC memerlukan suplai tegangan yang searah pada kumparan medan untuk diubah menjadi energi mekanik. Dalam motor DC terdapat dua kumparan yaitu kumparan medan yang berfungsi untuk menghasilkan magnet dan kumparan jangkar yang berfungsi sebagai tempat terbentuknya gaya gerak listrik (ggl E).[12] Motor DC yang digunakan dalam penelitian ini disajikan pada Gambar 5.

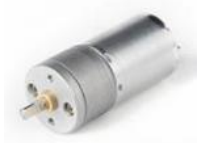

Gambar 5. Modul Motor

\section{2.2.8 Komunikasi Wireless}

Jaringan nirkabel atau Wireless LAN adalah teknologi jaringan yang tidak menggunakan perangkat kabel yang umumnya dijumpai di dalam sebuah jaringan komputer. Teknologi ini sesuai dengan namanya wireless yang artinya tanpa kabel, memanfaatkan gelombang radio untuk melakukan interaksi atau komunikasi antar unit komputer.[13]

\subsubsection{Arduino IDE}

Arduino adalah sebuah platform open source berbasiskan rangkaian input / output sederhana (I/O) dan lingkungan pengembangan yang mengimplementasikan bahasa Processing.[14] Software Arduino IDE digunakan dalam penelitian ini yang disajikan dalam Gambar 6 .

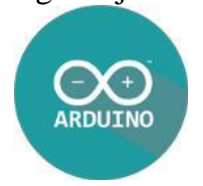

Gambar 6. Logo Software Arduino IDE

\section{Metode Penelitian}

Metode penelitian merupakan alur dari penelitian yang digunakan dalam perancangan robot pemotong rumput otomatis menggunakan wireless kontroler menggunakan modul ESP32-CAM berbasis Internet of Things (IoT) dan pengujian alat sebagai hasil dari penelitian. Metode penelitian disajikan pada Gambar 7. 


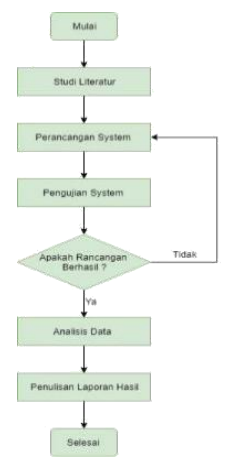

Gambar 7. Flowchart tahapan penelitian

Pada Gambar 7. adalah flowchart tahapan penelitian yang berguna untuk menyelesaikan penelitian ini berikut penjelasanya:

1. Studi Literatur: kegiatan yang terhubung dengan metode pengumpulan data pustaka, mengelola bahan penelitian, membaca dan mencatat.

2. Perancangan sistem : merancang atau mendesain robot pemotong rumput dengan baik yang mana berisi tentang persiapan alat dan perancang sesuai sistem yang direncanakan.

3. Pengujian sistem : menguji fungsi masingmasing alat dari perancangan sistem dan pengujian langsung di lapangan rumput. Pengujian fungsi dilakukan dengan metode black box testing. Pengujian langsung dilakukan pada lapangan rumput dengan berbagai keadaan yaitu rumput biasa, rumput berbatu, rumput berpasir, dan rumput berair.

4. Analisis data : menganalisis semua data hasil uji coba robot. Data hasil uji coba sistem dan uji coba langsung diperoleh dari hasil pengujian sistem dan pengujian langsung. Analisis data digunakan untuk mengetahui fungsionalitas masing-masing alat yang ada pada rancangan robot pemotong rumput.

5. Penulisan laporan hasil : menulis seluruh hasil dari penelitian yang sudah diuji dan disimpulkan.

\subsection{Rancangan Sistem}

\section{Desain Rancangan Sistem}

Alat pemotong rumput yang dirancang dalam penelitian ini menggunakan kontrol melalui web browser pada perangakat laptop atau komputer dan smartphone. Desain rancangan sistem disajikan pada gambar 8 .

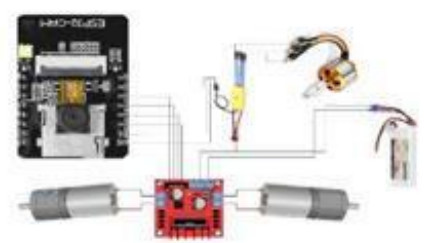

Gambar 8. Rancangan sistem robot pemotong rumput

Gambar 8. menjelaskan rancangan keseluruhan sistem yang akan dibangun dalam penelitian ini. Robot pemotong rumput dapat berjalan apabila robot sudah terkoneksi dengan perangkat komputer, laptop dan smartphone. Setelah terkoneksi robot akan menjalankan mikrokontroler yang mana berfungsi sebagai pengendali dari robot agar dapat dikontrol secara otomatis. Dan modul kamera yang ada di robot berfungsi untuk menampilkan gambar secara real time di dalam layar pengontrol agar lebih mudah dalam proses pemotongan rumput dengan jarak jauh. Setelah robot terkoneksi dengan alat pengontrol, maka bisa menyalakan brushless yang berguna untuk memotong rumput. Dan pengguna bisa memotong rumput yang panjang akan menjadi rapi dan juga bersih sehingga menjadikan lingkungan yang rapi.

2. Flowchart Penjelasan Penggunaan Robot

Robot pemotong rumput menggunakan flowchart sebagai penjelasan tentang tata cara penggunaan robot pemotong rumput. Flowchart penjelasan pada penelitian ini disajikan pada Gambar 9.

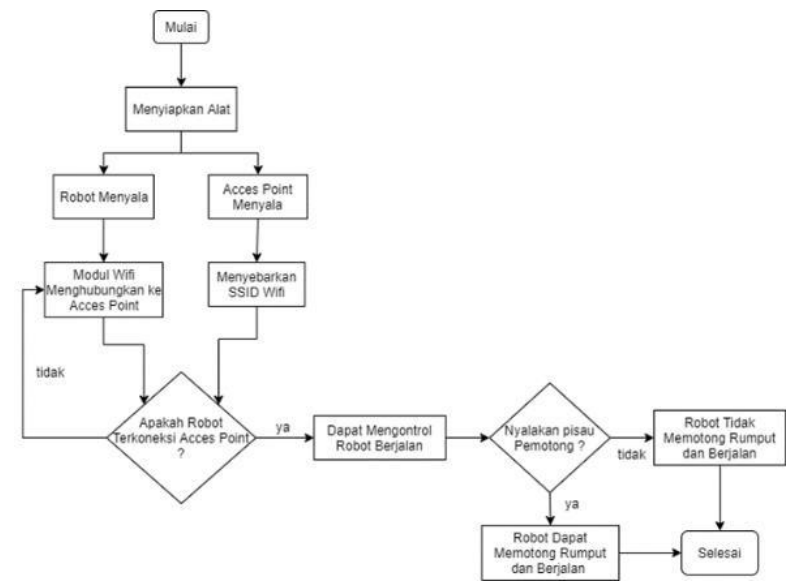

Gambar 9. flowchart alur robot

Pada Gambar 9. menjelaskan flowchart penggunaan robot pemotong rumput, yang pertama adalah menyiapkan alat yang akan digunakan untuk memotong rumput. Kemudian nyalakan robot pemotong rumput maka modul wifi dan modul kamera akan menyala dan nyalakan acces point yang berguna sebagai penghubung antara robot dan kontroler, modul wifi ESP32 akan mengkoneksikan ke acces point yang sudah terhubung dengan kontroler robot pemotong rumput. Apabila robot sudah teroneksi dengan acces point dan juga perangkat sebagai kontroler juga terkoneksi ke acces point, maka robot dapat dikontrol dengan perangkat tersebut. Jika robot belum terkoneksi dengan acces point maka robot akan mengulang untuk menghubungkan ke acces point sampai bisa terhubung ke acces point tersebut. Setelah perangkat terkoneksi robot sudah bisa dikontrol, apabila robot langsung digunakan untuk memotong rumput maka brushless harus dihidupkan, yang berguna sebagai pisau pemotong rumput dan robot bisa memotong rumput yang ada di sekitar dan apabila brushless pemotong rumput tidak dinyalakan maka robot hanya bisa berjalan, tidak dapat memotong rumput yang ada di sekitarnya.

Pengontrolan jarak robot pemotong rumput menggunakan modul wifi ESP32 yang mampu dikontrol sejauh $50 \mathrm{~m}$ di lapangan terbuka. Untuk melihat hasil pemotongan rumput digunakan modul kamera yang ada 
pada modul ESP32-CAM sebagai pengambilan data gambar medan.

3. Blok Diagram Robot Pemotong Rumput

Penggunaan blok diagram pada penelitian menggambarkan penggunaan alat pemotong rumput yang akan terkoneksi dengan laptop dan smartphone yang mana dapat dikendalikan oleh manusia. Rancangan blok diagram pada penelitian ini disajikan pada Gambar 10.

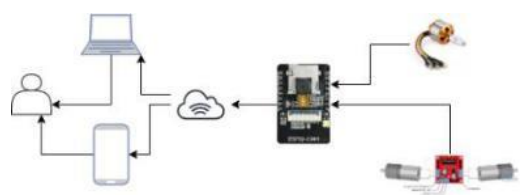

Gambar 10. Blok diagram robot pemotong rumput

Pada Gambar 10. menjelaskan tentang sistem kendali dalam bentuk rangkaian elektronika dan juga program kendalinya. User menggunakan perangkatnya sebagai alat pengendali yang terhubung dengan wifi sehingga dapat mengontrol beberapa modul yang terkoneksi dengan mikrokontroler ESP32-CAM seperti modul kamera OVO2640, motor driver L289N dan motor brushless.

4. Desain Robot Pemotong Rumput

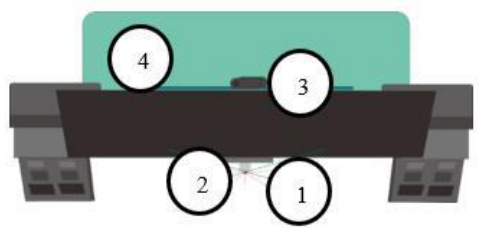

Gambar 11. Desain Robot Pemotong Rumput

Gambar 11. merupakan desain tampilan depan pada robot pemotong rumput otomatis yang memiliki beberapa fungsi sebagai berikut:

1. pemotong berfungsi mata pemotong robot.

2. Brushless with ESC-30A berfungsi sebagai penggerak alat pemotong rumput.

3. Modul kamera Arduino berfungsi sebagai alat untuk memonitoring dalam pemotongan rumput.

4. Case Board ESP32-CAM berfungsi untuk melindungi Arduino dari kotoran dan juga air.

5. Desain Tampilan Kontroler Robot

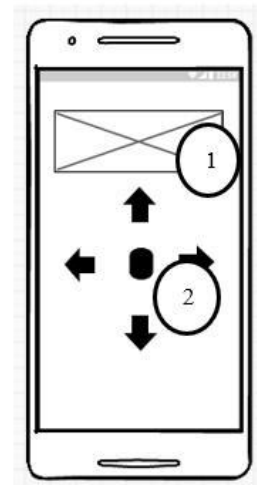

Gambar 12. Desain kontroler pada smartphone

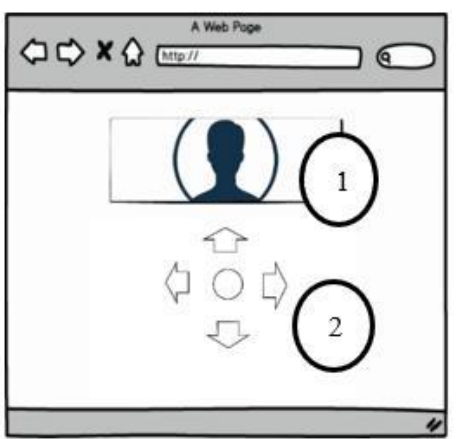

Gambar 13. Desain kontroler pada laptop

Pada gambar 12. ialah desain dari kontroler robot pada perangkat smartphone yang mana berfungsi untuk mengoperasikan robot pemotong rumput dan terdiri dari beberapa fungsi yaitu:

1. Tampilan dari modul kamera Arduino berfungsi untuk menampilkan gambar rumput yang mana dapat di potong oleh robot pemotong rumput.

2. Kontroller robot berfungsi sebagai pengontrol robot maju, mundur, kanan dan kiri.

Dan pada gambar 13. ialah desain dari kontroler robot pada perangkat komputer atau laptop yang mana berfungsi untuk mengoperasikan robot pemotong rumput dan terdiri dari beberapa fungsi yaitu:

1. Tampilan dari modul kamera Arduino berfungsi untuk menampilkan gambar rumput yang akan di potong oleh robot pemotong rumput.

2. Kontroler robot berfungsi sebagai pengontrol robot untuk bergerak maju, mundur,kanan dan kiri.

\section{Hasil dan Pembahasan}

\subsection{Implementasi}

1. Hasil Prototype Robot Pemotong Rumput

Rancangan alat dari penelitian ini adalah prototype dari robot pemotong rumput otomatis dengan kontrol ESP32-CAM menggunakan modul brushless with ESC30A dan kebel pemotong rumput berbasis Internet of Things (IoT). Hasil dari rancangan alat dalam penelitian ini disajikan pada gambar 14 . 


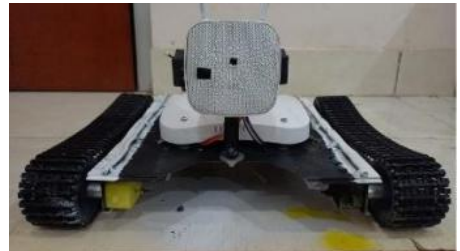

Gambar 14. Hasil prototype robot pemotong rumput

Pada gambar 14. adalah hasil perancangan robot pemotong rumput terlihat dari depan. Robot pemotong rumput otomatis dengan kontrol ESP32-CAM dalam penelitian ini menggunakan beberapa komponen dasar yang dibutuhkan dalam perancangan alat yaitu modul Mikrokontroler ESP32-CAM, motor driver L289N, motor DC, brushless dan ESC30A.

2. Hasil Desain Tampilan Kontroler Robot

Hasil rancangan desain tampilan kontroler pada web browser smartphone dan laptop, yang berfungsi untuk menjalankan robot pemotong rumput dari browser smartphone, dan juga untuk menampilkan video stream ketika robot akan memotong rumput. Hasil desain tampilan kontroler robot disajikan pada Gambar 4.2 dan Gambar 15.

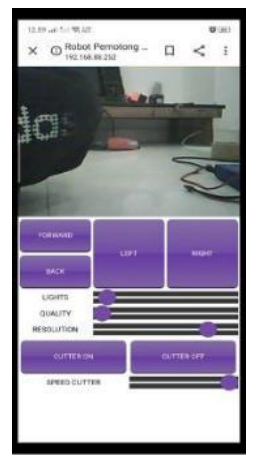

Gambar 15. Hasil desain kontroler pada smartphone

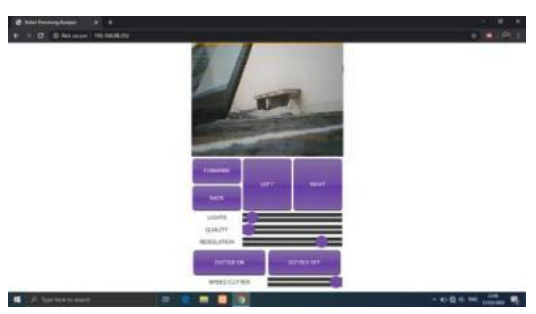

Gambar 16. hasil desain kontroler pada laptop

Pada Gambar 15. adalah hasil dari desain tampilan untuk mengontrol robot pemotong rumput otomatis dengan web browser pada smartphone. Dan pada Gambar 16. adalah hasil dari rancangan desain tampilan kontroler robot pemotong rumput pada web browser perangkat laptop atau komputer.

3. Modul ESP32-CAM

Hasil dari penempatan modul Mikrokontroler ESP32CAM berfungsi sebagai media kontrol robot dengan menggunakan wireless connection dan modul kamera OVO2640 berfungsi sebagai monitoring rumput yang akan dipotong, hasil penempatan modul mikrokontroler ESP32CAM disajikan dalam gambar 17.

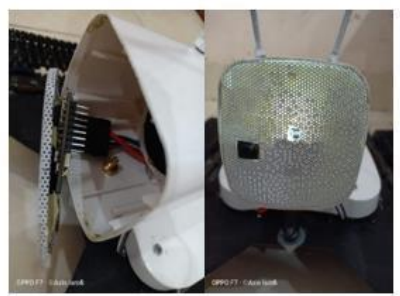

Gambar 17. Hasil Penempatan Modul Mikrokontroler ESP32-CAM

Pada Gambar 17. adalah hasil dari kepala robot dan penempatan modul ESP32-CAM untuk media kontrol wireless dan monitoring rumput. Apabila modul ESP32 terkoneksi dengan access point, maka robot dapat dijalankan dengan ip address yang didapatkan dari access point yang akan terhubung ke web browser pada komputer atau smartphone, dan modul kamera OVO2640 akan menampilkan gambar pada web browser, sehingga robot dapat dijalankan dengan wireless controller dan dapat memonitoring rumput yang akan dipotong dengan web browser

4. Modul Motor Driver L289N dan Modul ESC 30A

Motor driver L289N yang berfungsi sebagai penggerak motor DC pada roda robot, sedangkan modul ESC30A berfungsi sebagai kontroler brushless dari mata pisau pemotong rumput. Motor driver L289N dan modul ESC30A pada rancangan robot pemotong rumput diletakkan pada bagian atas body robot. Hasil dari rancangan penempatan Motor Driver L289N dan ESC30A pada robot pemotong rumput otomatis disajikan dalam gambar 18 .

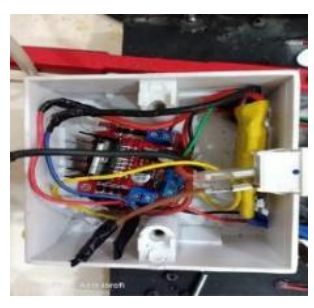

Gambar 18. Hasil Penempatan Modul Motor Driver L289N dan Modul ESC30A

Pada gambar 18. menjelaskan tentang perancangan penempatan Motor Driver L289N sebagai pengerak motor DC, yang akan jadi penggerak roda robot pemotong rumput. Serta ESC30A sebagai pengontrol dan penggerak motor brushless, yang berfungsi sebagai mata pisau pemotong rumput

5. Modul Motor Brushless

Hasil dari penempatan rancangan Motor Brushless yang berfungsi sebagai penggerak dari mata pisau pemotong rumput, hasil penenmpatan motor brushless dalam penelitian ini disajikan dalam Gambar 19. 


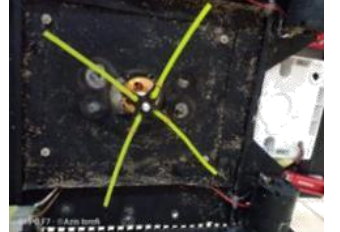

Gambar 19. Hasil Penempatan Motor Brushless Sebagai Penggerak Mata Pemotong Rumput

Pada Gambar 19. adalah hasil dari penempatan Motor Brushless pada robot pemotong rumput, yang berfungsi sebagai penggerak dari mata pisau pemotong rumput yang mana akan memotong rumput yang perlu dipotong.

\subsection{Pengujian}

1. Pengujian Modul Wifi (Outdoor)

Uji coba keseluruhan komponen pada penelitian ini dilakukan pada ruangan terbuka agar tidak mengganggu penyebaran sinyal Wifi. Pada uji coba ini penggunaan acces point sebagai penghubung antara robot pemotong rumput dengan perangkat smartphone dan laptop. Untuk mengakses kontroler dengan menggunakan ip address untuk membuka kontroler di web browser ke perangkat yang terhubung dengan acces point tesebut. Uji coba yang dilakukan pada modul Wifi bertujuan untuk mengetahui jarak kendali robot pemotong rumput. Hasil uji coba jarak acces point ke robot pemotong rumput disajikan pada Tabel 1 .

Tabel 1. hasil uji coba jarak acces point ke robot pemotong rumput

\begin{tabular}{|c|c|c|c|}
\hline No & Jarak & Status & Keterangan \\
\hline 1 & $\begin{array}{l}1-5 \\
\text { Meter }\end{array}$ & Terkoneksi & $\begin{array}{c}\text { Robot dapat } \\
\text { dikendalikan dengan } \\
\text { baik }\end{array}$ \\
\hline 2 & $\begin{array}{l}6-10 \\
\text { Meter }\end{array}$ & Terkoneksi & $\begin{array}{c}\text { Robot dapat } \\
\text { dikendalikan dengan } \\
\text { baik }\end{array}$ \\
\hline 3 & $\begin{array}{l}11-15 \\
\text { Meter }\end{array}$ & Terkoneksi & $\begin{array}{c}\text { Robot dapat } \\
\text { dikendalikan dengan } \\
\text { baik }\end{array}$ \\
\hline 4 & $\begin{array}{l}16-20 \\
\text { Meter }\end{array}$ & Terkoneksi & $\begin{array}{c}\text { Robot dapat } \\
\text { dikendalikan dengan } \\
\text { baik }\end{array}$ \\
\hline 5 & $\begin{array}{l}21-25 \\
\text { Meter }\end{array}$ & Terkoneksi & $\begin{array}{c}\text { Robot dapat } \\
\text { dikendalikan dengan } \\
\text { baik } \\
\end{array}$ \\
\hline 6 & $\begin{array}{c}26 \\
\text { Meter }\end{array}$ & $\begin{array}{l}\text { Koneksi } \\
\text { Melemah }\end{array}$ & $\begin{array}{c}\text { Robot dapat } \\
\text { dikendalikan dengan } \\
\text { delay }\end{array}$ \\
\hline 7 & $\begin{array}{c}27 \\
\text { Meter }\end{array}$ & $\begin{array}{l}\text { Koneksi } \\
\text { Melemah }\end{array}$ & $\begin{array}{c}\text { Robot dapat } \\
\text { dikendalikan dengan } \\
\text { delay }\end{array}$ \\
\hline 8 & $\begin{array}{c}28 \\
\text { Meter }\end{array}$ & $\begin{array}{l}\text { Koneksi } \\
\text { Melemah }\end{array}$ & $\begin{array}{c}\text { Robot dapat } \\
\text { dikendalikan dengan } \\
\text { delay } \\
\end{array}$ \\
\hline 9 & $\begin{array}{c}29 \\
\text { Meter }\end{array}$ & $\begin{array}{l}\text { Koneksi } \\
\text { Melemah }\end{array}$ & $\begin{array}{c}\text { Robot dapat } \\
\text { dikendalikan dengan }\end{array}$ \\
\hline
\end{tabular}

\begin{tabular}{|c|c|c|c|}
\hline & & & delay \\
\hline 10 & $\begin{array}{c}30 \\
\text { Meter }\end{array}$ & $\begin{array}{l}\text { Koneksi } \\
\text { Melemah }\end{array}$ & $\begin{array}{c}\text { Robot dapat } \\
\text { dikendalikan dengan } \\
\text { delay }\end{array}$ \\
\hline 11 & $\begin{array}{l}31-35 \\
\text { Meter }\end{array}$ & Terputus & $\begin{array}{c}\text { Robot tidak dapat } \\
\text { dikendalikan }\end{array}$ \\
\hline
\end{tabular}

Pada Tabel 1. berfungsi untuk mengetahui data jarak acces point ke robot robot pemotong rumput dengan modul Wifi yang ada pada Mikrokontroler. Pada jarak 1 - 25 meter, acces point ke robot pemotong rumput dapat dikendalikan dengan baik. pada jarak 25 30 meter, acces point ke robot pemotong rumput koneksi mulai melemah dan robot dapat dikendalikan dengan delay. Dan pada jarak 31 meter ke atas, acces point ke robot pemotong rumput koneksi Wifi terputus dan robot tidak dapat dikendalikan. Hal ini berarti robot pemotong rumput dapat dikendalikan dengan baik pada jarak 25 meter antara acces point.

Dan hasil uji coba jarak acces point ke perangkat smartphone dan laptop atau komputer sebagai kontoler robot disajikan pada Tabel 2 .

Tabel 2. Hasil uji coba jarak acces point ke perangkat kontroler

\begin{tabular}{|c|c|c|c|}
\hline No & Jarak & Status & Keterangan \\
\hline 1 & $\begin{array}{l}1-5 \\
\text { Meter }\end{array}$ & Terkoneksi & $\begin{array}{c}\text { Perangkat dapat } \\
\text { mengendalikan robot } \\
\text { dengan baik }\end{array}$ \\
\hline 2 & $\begin{array}{l}6-10 \\
\text { Meter }\end{array}$ & Terkoneksi & $\begin{array}{c}\text { Perangkat dapat } \\
\text { mengendalikan robot } \\
\text { dengan baik }\end{array}$ \\
\hline 3 & $\begin{array}{l}11-15 \\
\text { Meter }\end{array}$ & Terkoneksi & $\begin{array}{c}\text { Perangkat dapat } \\
\text { mengendalikan robot } \\
\text { dengan baik }\end{array}$ \\
\hline 4 & $\begin{array}{l}16-20 \\
\text { Meter }\end{array}$ & Terkoneksi & $\begin{array}{c}\text { Perangkat dapat } \\
\text { mengendalikan robot } \\
\text { dengan baik }\end{array}$ \\
\hline 5 & $\begin{array}{l}21-25 \\
\text { Meter }\end{array}$ & Terkoneksi & $\begin{array}{c}\text { Perangkat dapat } \\
\text { mengendalikan robot } \\
\text { dengan baik }\end{array}$ \\
\hline 6 & $\begin{array}{c}26 \\
\text { Meter }\end{array}$ & $\begin{array}{l}\text { Koneksi } \\
\text { Melemah }\end{array}$ & $\begin{array}{c}\text { Perangkat dapat } \\
\text { mengendalikan robot } \\
\text { dengan delay }\end{array}$ \\
\hline 7 & $\begin{array}{c}27 \\
\text { Meter }\end{array}$ & $\begin{array}{l}\text { Koneksi } \\
\text { Melemah }\end{array}$ & $\begin{array}{c}\text { Perangkat dapat } \\
\text { mengendalikan robot } \\
\text { dengan delay }\end{array}$ \\
\hline 8 & $\begin{array}{c}28 \\
\text { Meter }\end{array}$ & $\begin{array}{l}\text { Koneksi } \\
\text { Melemah }\end{array}$ & $\begin{array}{c}\text { Perangkat dapat } \\
\text { mengendalikan robot } \\
\text { dengan delay }\end{array}$ \\
\hline 9 & $\begin{array}{c}29 \\
\text { Meter }\end{array}$ & $\begin{array}{l}\text { Koneksi } \\
\text { Melemah }\end{array}$ & $\begin{array}{c}\text { Perangkat dapat } \\
\text { mengendalikan robot } \\
\text { dengan delay }\end{array}$ \\
\hline 10 & $\begin{array}{c}30 \\
\text { Meter }\end{array}$ & $\begin{array}{l}\text { Koneksi } \\
\text { Melemah }\end{array}$ & $\begin{array}{c}\text { Perangkat dapat } \\
\text { mengendalikan robot } \\
\text { dengan delay }\end{array}$ \\
\hline 11 & $\begin{array}{l}1-35 \\
\text { Meter } \\
\end{array}$ & Terputus & $\begin{array}{l}\text { Perangkat tidak dapat } \\
\text { mengendalikan robot }\end{array}$ \\
\hline
\end{tabular}


Pada Tabel 2. berfungsi untuk mengetahui data jarak antara acces point ke perangkat smartphone dan laptop atau komputer. Pada jarak $1-25$ meter, perangkat kontroler dapat mengendalikan robot dengan baik. Pada jarak 26 - 30 meter, perangkat kontroler dapat mengendalikan robot dengan delay, dan pada jarak 31 ke atas perangkat kontroler tidak dapat mengendalikan robot.

Dari hasil uji coba modul Wifi sebagai kontroler robot pemotong rumput di ruang terbuka, dapat disimpulkan bahwa jarak kendali robot pemotong dengan web browser pada smartphone dan laptop atau komputer, dengan jarak maximal 50 meter tanpa ada halangan. Yang mana data jarak tersebut didapatkan dari Tabel 1. dan Tabel 2, yaitu dengan jarak acces point ke robot pemotong rumput yang berjarak maximal 25 meter dan jarak acces point ke perangkat kontroler yang berjarak maximal 25 meter.

\section{Pengujian Modul Wifi (Indoor)}

Hasil uji coba kontroler robot pemotong rumput dengan modul Wifi yang dilakukan di ruangan tertutup. Sama halnya dengan uji coba yang dilakukan di luar ruangan yaitu digunakan acces point sebagai penghubung antara robot pemotong rumput dengan perangkat kontroler. Hasil uji coba kontroler robot pemotong rumput dengan modul Wifi disajikan pada Gambar 20.

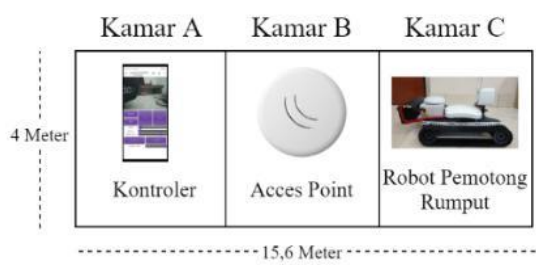

Gambar 20. Hasil uji kontroler dengan modul Wifi di ruangan tertutup

Dari Gambar 20. dapat disimpulkan bahwa robot pemotong rumput dapat dikontrol di ruangan tertutup, akan tetapi ada delay ketika melakukan perintah dari perangkat ke robot pemotong rumput, dikarenakan frekuensi pada modul wifi terhalang oleh dinding sehingga koneksi pada kontroler robot menjadi delay. Dengan ukuran ruang sebesar 4 x 5,2 meter dengan total pengujian menggunakan 3 kamar sebagai uji coba modul wifi.

3. Pengujian Mata Pisau Pemotong Rumput

Dari hasil uji coba pisau pemotong rumput dengan menggunakan flexible shaft atau kabel tulang pemotong rumput, dapat disimpulkan bahwa rumput dapat dipotong dengan robot pemotong rumput yang dirancang pada penelitian ini. Dengan hasil potongan yang berbeda tergantung kondisi rumput pada saat akan dipotong. Pada uji coba ini digunakan beberapa medan sebagai pengujian dari robot pemotong rumput, medan yang dipakai antara lain: rumput biasa, rumput berbatu, rumput berpasir dan rumput berair. Dari hasil uji dengan medan tersebut dapat disimpulkan bahwa robot dapat memotng rumput kecuali pada medan yang berair dikarenakan robot yang dirancang pada penelitian ini tidak anti air. Hasil uji coba pemotongan rumput dengan kondisi tertentu disajikan pada Gambar 21.

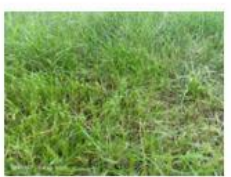

A

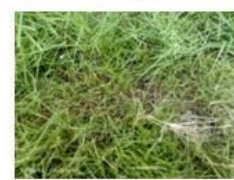

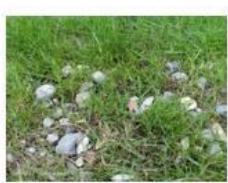

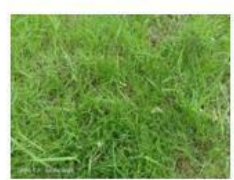

Gambar 21. Hasil pemotongan rumput dengan mata pisau pemotong rumput

Data hasil uji coba mata pisau pemotong rumput dengan hasil potongan rumput yang berbeda sesuai dengan kondisi robot ketika proses memotong rumput. Data hasil uji coba dapat disajikan pada Tabel 3.

Tabel 3. Hasil uji coba pisau pemotong rumput

\begin{tabular}{|c|c|c|c|c|}
\hline $\begin{array}{c}\text { Kondisi } \\
\text { lapanga } \\
\mathrm{n}\end{array}$ & $\begin{array}{c}\text { Panjang } \\
\text { rumput } \\
\text { (sebelum } \\
\text { ) }\end{array}$ & $\begin{array}{c}\text { Kondisi } \\
\text { rumput } \\
\text { (sesudah } \\
\text { ) }\end{array}$ & $\begin{array}{c}\text { Gamba } \\
\mathrm{r} \\
\text { rumput }\end{array}$ & hasil \\
\hline $\begin{array}{c}\text { Rumput } \\
\text { biasa }\end{array}$ & $7 \mathrm{~cm}$ & $2 \mathrm{~cm}$ & $\begin{array}{c}\text { Gamba } \\
\text { r 21.A }\end{array}$ & $\begin{array}{c}\text { Terpoton } \\
\mathrm{g}\end{array}$ \\
\hline $\begin{array}{c}\text { Rumput } \\
\text { berbatu }\end{array}$ & $7 \mathrm{~cm}$ & $3 \mathrm{~cm}$ & $\begin{array}{c}\text { Gamba } \\
\text { r 21.B }\end{array}$ & $\begin{array}{c}\text { Terpoton } \\
\mathrm{g}\end{array}$ \\
\hline $\begin{array}{c}\text { Rumput } \\
\text { berpasir }\end{array}$ & $7 \mathrm{~cm}$ & $4 \mathrm{~cm}$ & $\begin{array}{c}\text { Gamba } \\
\text { r 21.C }\end{array}$ & $\begin{array}{c}\text { Terpoton } \\
\mathrm{g}\end{array}$ \\
\hline $\begin{array}{c}\text { Rumput } \\
\text { berair }\end{array}$ & $7 \mathrm{~cm}$ & $7 \mathrm{~cm}$ & $\begin{array}{c}\text { Gamba } \\
\text { r 21.D }\end{array}$ & $\begin{array}{c}\text { Tidak di } \\
\text { uji coba }\end{array}$ \\
\hline
\end{tabular}

Pada Tabel 3. adalah hasil uji coba fungsional dari mata pisau pemotog rumput dengan medan potong yang berbeda, yang mana robot dapat memotong rumput kecuali pada medan yang berair, dikarenakan robot tidak anti air.

4. Pengujian Kecepatan Brushless

Hasil uji coba dari kecepatan pisau pemotong rumput dengan menggunakan motor brushless dapat disimpulkan bahwa kecepatan pisau pemotong rumput dapat berutar pada nilai maximalnya. Pada pengukuran kecepatan pisau pemotong rumput pada percobaan yang dilakukan, yaitu dengan menggunakan rumus yang diperoleh dari pengiriman data dari kontroler robot melalui web browser yang akan menghasilkan kecepatan dari mata pisau pemotong rumput. Rumus yang digunakan sebagai berikut:

Keterangan:

$$
\text { speed = val } * \text { endpoint }
$$

Speed: kecepatan putaran brushless dengan range nilai minimal hingga maximal. 
Val: nilai yang didapatkan dari kontroler yang ada pada web browser, dengan range nilai 0 hingga 8 .

Endpoint: nilai yang tetap yaitu 250/s, yang mana akan menghasilkan kecepatan pada speed brushless dengan nilai minimalnya 250 hingga maximalnya 2000.Dari rumus penghitungan di atas mendapatkan hasil dari kecepatan piasu pemotong rumput yang disajikan pada Gambar 22.

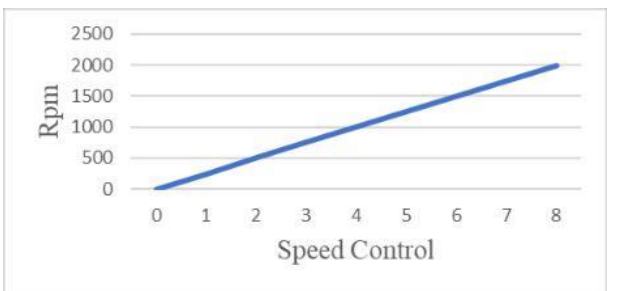

Gambar 22. Hasil uji coba kecepatan actuator

Pada Gambar 22. adalah hasil uji coba kecepatan motor brushless pada pemotong rumput, yang mana nilai kecepatan minimal $0 \mathrm{Rpm}$ dan kecepatan maximal 2000Rpm. Dari hasil pengujian speed kontroler pada pemotong rumput dapat disimpulkan bahawa mata pisau pemotong rumput dapat memotong rumput dengan kecepatan sesuai dengan ketebalan rumput yang akan dipotong.

5. Pengujian Baterai pada Robot

Dari hasil uji coba penggunaan baterai memiliki beberapa parameter yang harus diperhatikan dalam pemilihan baterai adalah jumlah sel (S), discharge (C) dan kapasitas (mAH). Jumlah sel menentukan voltase dari baterai tersebut pada keadaan kosong $1 \mathrm{~S}=3,7 \mathrm{~V}$, $2 \mathrm{~S}=7,4 \mathrm{~V}, 3 \mathrm{~S}=11,1 \mathrm{~V}$ dan seterusnya (kelipatan 3,7V). Kemudian discharge (C) memperhatikan seberapa besar kecepatan arus yang dapat dikeluarkan, dan kapasitas (mAH) menunjukan berapa lama baterai tersebut dapat bekerja pada amper tertentu. Pada penelitian kali ini digunakan kapasitas baterai yaitu 2200mAh, yang mana dapat diperkirakan baterai dapat bertahan pada 2200/1000 = 2,2 Ampere selama 1 jam.

Untuk mengetahui nilai Ampere(arus) dapat digunakan nilai discharge dengan cara mengalikanya dengan nilai kapasitas baterai. Pada penelitian ini digunakan baterai dengan kapasitas 2200mAH dan discharge 25C maka baterai akan menghasilkan arus yang didapat dari $2200 \times 25 / 1000=55$ Ampere. Jadi nilai arus baterai yang digunakan pada penelitian ini adalah 55Ampere. Nilai ampere dari baterai harus lebih besar atau sama dengan ampere yang dibutuhkan oleh robot, jika lebih sedikit baterai akan cepet panas dan rusak. Adapun daya baterai dapat dihitung yaitu daya $=$ Ampere $\mathrm{x}$ Volt, nilai Volt baterai yang digunakan pada penelitian ini adalah $11.1 \mathrm{~V}$, maka nilai daya didapatkan dari daya $=55 \mathrm{~A} \times 11.1 \mathrm{~V}=$ 610,5 Watt[15]. Daya tersebut harus lebih besar dari pada yang dibutuhkan oleh robot. Hasil uji coba penggunaan baterai pada motor driver L289N dengan menggunakan iMAX B6AC Profesional Balance Charger/Discharger, dengan durasi uji coba yang berbeda
- beda. Hasil uji coba penggunaan baterai pada motor driver L289N disajikan pada Tabel 4.

Tabel 4. Hasil Uji Coba Penggunaan Baterai Pada Motor Driver L289N

\begin{tabular}{|c|c|c|c|c|c|c|c|}
\hline \multirow{2}{*}{$\begin{array}{l}\text { Duras } \\
\quad \mathrm{i}\end{array}$} & \multicolumn{3}{|c|}{$\begin{array}{c}\text { kondisi awal } \\
\text { batera } \\
\mathrm{i}\end{array}$} & \multicolumn{3}{|c|}{$\begin{array}{c}\text { Kondisi akhir } \\
\text { batera } \\
\text { i }\end{array}$} & \multirow{2}{*}{$\begin{array}{l}\text { Total } \\
\left(\begin{array}{c}\text { Volt } \\
\text { ) }\end{array}\right.\end{array}$} \\
\hline & $\begin{array}{c}\text { Sel } \\
1\end{array}$ & \begin{tabular}{|c} 
Sel \\
2
\end{tabular} & $\begin{array}{c}\text { Sel } \\
3\end{array}$ & $\begin{array}{c}\text { Sel } \\
1\end{array}$ & $\begin{array}{c}\text { Sel } \\
1\end{array}$ & $\begin{array}{c}\text { Sel } \\
3\end{array}$ & \\
\hline $\begin{array}{l}1 \\
\text { menit }\end{array}$ & $\begin{array}{l}4,0 \\
6 \mathrm{~V}\end{array}$ & $\begin{array}{l}4,0 \\
5 \mathrm{~V}\end{array}$ & $5 \mathrm{~V}$ & $5 \mathrm{~V}$ & $\begin{array}{c}4,0 \\
4 \\
\mathrm{~V}\end{array}$ & $4 \mathrm{~V}$ & $\begin{array}{r}0,03 \\
\mathrm{~V}\end{array}$ \\
\hline $\begin{array}{l}5 \\
\text { menit }\end{array}$ & $\begin{array}{l}4,0 \\
5 \mathrm{~V}\end{array}$ & 4,0 & 4,0 & 3,9 & $\begin{array}{c}3,9 \\
9 \\
V\end{array}$ & 3,9 & 0,17 \\
\hline $\begin{array}{l}10 \\
\text { menit }\end{array}$ & $\begin{array}{l}3,9 \\
9 \mathrm{~V}\end{array}$ & $\begin{array}{l}3,9 \\
9 \mathrm{~V}\end{array}$ & $8 \mathrm{~V}$ & $8 \mathrm{~V}$ & $\begin{array}{c}3,8 \\
8 \\
\mathrm{~V}\end{array}$ & $7 \mathrm{~V}$ & 0,33 \\
\hline menit & 3,8 & 3,8 & 3,8 & 3,6 & $\begin{array}{c}3,6 \\
8 \\
\mathrm{~V}\end{array}$ & 3,6 & 0,60 \\
\hline
\end{tabular}

Pada Tabel 4. adalah hasil uji coba dari total penggunaan daya baterai pada modul motor driver L289N, dari total penggunaan baterai selama 1 menit yaitu sebesar $0,03 \mathrm{~V}$.

Hasil uji coba penggunaan baterai pada Brushless dengan menggunaakan iMax B6AC Profesional Balance Charger/Discharger, pada penggunaan speed motor brushless nilaimin sampai nilaimax. hasil uji coba pengunaan baterai pada motor brushless disajikan pada Tabel 5.

Tabel 5. Hasil Uji Coba Baterai pada Brushless

\begin{tabular}{|c|c|c|c|c|c|c|c|c|}
\hline \multirow{2}{*}{$\begin{array}{c}\text { Spe } \\
\text { ed }\end{array}$} & \multirow{2}{*}{$\begin{array}{c}\text { Dur } \\
\text { asi }\end{array}$} & \multicolumn{3}{|c|}{$\begin{array}{c}\text { Kondisi Awal } \\
\text { Baterai }\end{array}$} & \multicolumn{3}{|c|}{$\begin{array}{l}\text { Kondisi Akhir } \\
\text { Baterai }\end{array}$} & \multirow{2}{*}{$\begin{array}{c}\text { Tot } \\
\text { al } \\
\text { (Vol } \\
\mathrm{t})\end{array}$} \\
\hline & & $\begin{array}{c}\text { Sel } \\
1\end{array}$ & $\begin{array}{c}\text { Sel } \\
2\end{array}$ & $\begin{array}{c}\mathrm{Sel} \\
3\end{array}$ & $\begin{array}{c}\text { Sel } \\
1\end{array}$ & $\begin{array}{c}\text { Sel } \\
2\end{array}$ & $\begin{array}{c}\text { Sel } \\
3\end{array}$ & \\
\hline 1 & $\begin{array}{c}1 \\
\text { men } \\
\text { it }\end{array}$ & $\begin{array}{c}3,7 \\
1 \\
\mathrm{~V}\end{array}$ & $\begin{array}{c}3,7 \\
2 \\
V\end{array}$ & $\begin{array}{c}3,6 \\
9 \\
\mathrm{~V}\end{array}$ & $\begin{array}{c}3,7 \\
0 \\
\mathrm{~V}\end{array}$ & $\begin{array}{c}3,7 \\
2 \\
V\end{array}$ & $\begin{array}{c}3,6 \\
9 \\
\mathrm{~V}\end{array}$ & $\begin{array}{l}0,0 \\
1 \mathrm{~V}\end{array}$ \\
\hline 2 & $\begin{array}{c}1 \\
\text { men } \\
\text { it }\end{array}$ & $\begin{array}{c}3,7 \\
0 \\
\mathrm{~V}\end{array}$ & $\begin{array}{c}3,7 \\
2 \\
V\end{array}$ & $\begin{array}{c}3,6 \\
9 \\
V\end{array}$ & $\begin{array}{c}3,6 \\
9 \\
V\end{array}$ & $\begin{array}{c}3,7 \\
1 \\
\mathrm{~V}\end{array}$ & $\begin{array}{c}3,6 \\
9 \\
\mathrm{~V}\end{array}$ & $\begin{array}{l}0,0 \\
2 \mathrm{~V}\end{array}$ \\
\hline 3 & $\begin{array}{c}1 \\
\text { men } \\
\text { it }\end{array}$ & $\begin{array}{c}3,6 \\
9 \\
V\end{array}$ & $\begin{array}{c}3,7 \\
1 \\
\mathrm{~V}\end{array}$ & $\begin{array}{c}3,6 \\
9 \\
\mathrm{~V}\end{array}$ & $\begin{array}{c}3,6 \\
9 \\
\mathrm{~V}\end{array}$ & $\begin{array}{c}3,6 \\
9 \\
V\end{array}$ & $\begin{array}{c}3,6 \\
8 \\
\mathrm{~V}\end{array}$ & $\begin{array}{l}0,0 \\
3 \mathrm{~V}\end{array}$ \\
\hline 4 & $\begin{array}{c}1 \\
\text { men } \\
\text { it }\end{array}$ & $\begin{array}{c}3,6 \\
9 \\
\mathrm{~V}\end{array}$ & $\begin{array}{c}3,6 \\
9 \\
V\end{array}$ & $\begin{array}{c}3,6 \\
8 \\
V\end{array}$ & $\begin{array}{c}3,6 \\
8 \\
V\end{array}$ & $\begin{array}{c}3,6 \\
8 \\
V\end{array}$ & $\begin{array}{c}3,6 \\
7 \\
\mathrm{~V}\end{array}$ & $\begin{array}{l}0,0 \\
4 \mathrm{~V}\end{array}$ \\
\hline 5 & $\begin{array}{c}1 \\
\text { men } \\
\text { it }\end{array}$ & $\begin{array}{c}3,6 \\
8 \\
V\end{array}$ & $\begin{array}{c}3,6 \\
8 \\
V\end{array}$ & $\begin{array}{c}3,6 \\
7 \\
\mathrm{~V}\end{array}$ & \begin{tabular}{|c}
3,6 \\
6 \\
$\mathrm{~V}$
\end{tabular} & $\begin{array}{c}3,6 \\
5 \\
V\end{array}$ & $\begin{array}{c}3,6 \\
5 \\
\mathrm{~V}\end{array}$ & $\begin{array}{l}0,0 \\
7 \mathrm{~V}\end{array}$ \\
\hline 6 & $\begin{array}{c}1 \\
\text { men } \\
\text { it }\end{array}$ & $\begin{array}{c}3,6 \\
6 \\
\mathrm{~V}\end{array}$ & $\begin{array}{c}3,6 \\
5 \\
V\end{array}$ & $\begin{array}{c}3,6 \\
5 \\
V\end{array}$ & \begin{tabular}{|c}
3,6 \\
3 \\
$\mathrm{~V}$
\end{tabular} & $\begin{array}{c}3,6 \\
2 \\
V\end{array}$ & $\begin{array}{c}3,6 \\
2 \\
\mathrm{~V}\end{array}$ & $\begin{array}{l}0,0 \\
9 \mathrm{~V}\end{array}$ \\
\hline & $\begin{array}{c}1 \\
\text { men }\end{array}$ & $\begin{array}{c}3,6 \\
3\end{array}$ & $\begin{array}{c}3,6 \\
2\end{array}$ & $\begin{array}{c}3,6 \\
2\end{array}$ & $\begin{array}{c}3,5 \\
9\end{array}$ & $\begin{array}{c}3,5 \\
8\end{array}$ & $\begin{array}{c}3,5 \\
9\end{array}$ & 0,11 \\
\hline
\end{tabular}




\begin{tabular}{|c|c|c|c|c|c|c|c|c|}
7 & it & $\mathrm{V}$ & $\mathrm{V}$ & $\mathrm{V}$ & $\mathrm{V}$ & $\mathrm{V}$ & $\mathrm{V}$ & $\mathrm{V}$ \\
\hline & 1 & 3,5 & 3,5 & 3,5 & 3,5 & 3,5 & 3,5 & \\
& men & 9 & 8 & 9 & 4 & 4 & 5 & 0,1 \\
8 & it & $\mathrm{V}$ & $\mathrm{V}$ & $\mathrm{V}$ & $\mathrm{V}$ & $\mathrm{V}$ & $\mathrm{V}$ & $3 \mathrm{~V}$ \\
\hline
\end{tabular}

Pada Tabel 5. adalah hasil uji coba penggunaan baterai pada brushless dengan durasi uji coba selama 1 menit, dengan perbedaan setiap speed anatara $0,01 \mathrm{~V}$ disetiap nilai speed pada motor brushless.

Hasil uji coba penggunaan baterai ke seluruh komponen yang digunakan pada penelitian ini yaitu motor driver L289N dan brushless, pengujian baterai sama dengan pengujian sebelumya yaitu dengan menggunakan $i M A X$ B6AC Profesional Balance Charger/Discharger. Hasil uji coba penggunaan baterai ke seluruh komponen disajikan pada Tabel 6.

Tabel 6. Hasil Uji Coba Penggunaan Baterai Pada Semua Komponen

\begin{tabular}{|c|c|c|c|c|}
\hline \multirow{2}{*}{$\begin{array}{c}\text { Speed } \\
\text { Brushless }\end{array}$} & \multirow{2}{*}{ Durasi } & \multicolumn{2}{|c|}{$\begin{array}{c}\text { Baterai Terpakai } \\
\text { Robot }\end{array}$} & \multirow{2}{*}{$\begin{array}{c}\text { Total } \\
\text { (volt) }\end{array}$} \\
\cline { 3 - 4 } & & Brushless & $\begin{array}{c}\text { Motor } \\
\text { Driver }\end{array}$ & \\
\hline 1 & $\begin{array}{c}1 \\
\text { menit }\end{array}$ & $0,01 \mathrm{~V}$ & $0,03 \mathrm{~V}$ & $\begin{array}{c}0,04 \\
\mathrm{~V}\end{array}$ \\
\hline 2 & $\begin{array}{c}1 \\
\text { menit }\end{array}$ & $0,02 \mathrm{~V}$ & $0,03 \mathrm{~V}$ & $\begin{array}{c}0,05 \\
\mathrm{~V}\end{array}$ \\
\hline 3 & $\begin{array}{c}1 \\
\text { menit }\end{array}$ & $0,03 \mathrm{~V}$ & $0,03 \mathrm{~V}$ & $\begin{array}{c}0,06 \\
\mathrm{~V}\end{array}$ \\
\hline 4 & $\begin{array}{c}1 \\
\text { menit }\end{array}$ & $0,04 \mathrm{~V}$ & $0,03 \mathrm{~V}$ & $\begin{array}{c}0,07 \\
\mathrm{~V}\end{array}$ \\
\hline 5 & $\begin{array}{c}1 \\
\text { menit }\end{array}$ & $0,07 \mathrm{~V}$ & $0,03 \mathrm{~V}$ & $\begin{array}{c}0,10 \\
\mathrm{~V}\end{array}$ \\
\hline 6 & $\begin{array}{c}1 \\
\text { menit }\end{array}$ & $0,09 \mathrm{~V}$ & $0,03 \mathrm{~V}$ & $\begin{array}{c}0,12 \\
\mathrm{~V}\end{array}$ \\
\hline 7 & $\begin{array}{c}1 \\
\text { menit }\end{array}$ & $0,11 \mathrm{~V}$ & $0,03 \mathrm{~V}$ & $\begin{array}{c}0,14 \\
\mathrm{~V}\end{array}$ \\
\hline 8 & $\begin{array}{c}1 \\
\text { menit }\end{array}$ & $0,13 \mathrm{~V}$ & $0,03 \mathrm{~V}$ & $\begin{array}{c}0,16 \\
\mathrm{~V}\end{array}$ \\
\hline & & & & \\
\hline
\end{tabular}

Pada Tabel 6. adalah hasil uji coba penggunaan baterai secara keseluruhan komponen yang digunakan pada penelitian ini. Maka dapat disimpulkan bahwa penggunaan baterai lippo $3 \mathrm{~S}$ dan discharge $25 \mathrm{C}$ pada penggunaan minimal selama 1 menit dengan total daya sebesar $0,04 \mathrm{~V}$ dan dalam keadaan maximal selama 1 menit total daya sebesar $0,16 \mathrm{~V}$.

\section{Kesimpulan}

Berdasarkan hasil uji coba dari keseluruhan alat, dapat disimpulkan bahwa alat ini dapat digunkan untuk memotong rumput dengan baik.Dari uji coba modul Wifi yang digunakan sebagai koneksi kontroler ini berfungsi dengan baik dengan jarak kontrol maximal 50 meter. Penggunaan motor brushless dapat memotong rumput dengan baik karena kecepatan yang dihasilkan dapat dikontrol, sehingga dapat menghemat penggunaan baterai sebesar $0,16 \mathrm{~V}$ permenit dengan kecepatan maximal. Maximal penggunaan robot pemotong rumput adalah 20 menit tanpa berhenti.

\section{Daftar Pustaka}

F. R. Hadiputra and T. K.

Priyambodo,"Purwarupa Pengendalian Jarak Jauh Pada Mobile Robot Berbasis Web Melalui Jaringan Wireless TCP/IP," IJEIS (Indonesian J. Electron. Instrum. Syst., vol. 6, no. 1, p. 105, 2016, doi: 10.22146/ijeis.15247.

J. Y. Akay, J. O. Wuwung, B. . A. Sugiarso, and A.

S. M. Lumenta, "Rancang Bangun Alat Pemotong Rumput Otomatis," E-Journal Tek. Elektro Dan Komput., pp. 1-6, 2013.

[3] A. Yusup, M. Arkanuddin, and T. Sutikno, "Perancangan Model Alat Pemotong Rumput Otomatis Berbasis Mikrokontroler AT89C51," J. Ilm. Tek. Elektro Komput. dan Inform., vol. 1, no. 1, pp. 21-32, 2015.

D. Aryani, M. Wahyudin, and M. Fazri, "PROTOTYPE ROBOT CERDAS PEMOTONG RUMPUT BERBASIS RASPBERRY Pi B + MENGGUNAKAN WEB BROWSER," Cerita, vol. 1, no. 1, pp. 1-10, 2015.

[5] R. Herdiansyah, "Rancangan Bangun Robot Pemotong Rumput Otomatis Berbasis Arduino Menggunakan Wireless Controller Dan Solar Cell," spinformatika170012, no. 6, pp. 67-72, 2017.

[6] P. Harahap and M. Schmidt, "Perancangan Alat Pemotong Rumput Otomatis Berbasis Arduino Uno Memakai Joystick," Semin. Nas. Tek. Elektro, pp. 181-184, 2018.

[7] A. Choudhry, "How to use ESP32 Camera Module for Video Streaming and Face Recognition," 4 november, 2019. [Online]. Available:

https://circuitdigest.com/microcontrollerprojects/how-to-use-esp32-camera-module-forvideo-streaming-and-face-recognition.

[8] A. Nurdianto, D. Notosudjono, and H. Soebagia, "Rancang bangun sistem peringatan dini banjir (early warning system) terintegrasi internet of things," J. Online Mhs. Bid. Tek. Elektro, vol. 01, pp. 1-10, 2018.

[9] Y. D. Widiarto, M. E. I. Najoan, M. D. Putro, and J. T. Elektro-ft, "Sistem Penggerak Robot Beroda Vacuum Cleaner Berbasis Mini Computer Raspberry Pi," E-Journal Tek. Elektro Dan Komput., vol. 7, no. 1, pp. 25-32, 2018, doi: 10.35793/jtek.7.1.2018.19140.

[10] N. M. A. S. and D. Mulyana, "Pengaturan Kecepatan Motor Brushless DC(Direct Current) Menggunakan Cuk Converter," J. Tek. Elektro dan Komput. TRIAC, vol. 6, no. 2, 2019, doi: 10.21107/triac.v6i2.5990.

[11] M. Syamsudin, "Perancangan Dan Pembuatan Aerosonde Berbasis Multirotor ( Quadqopter ) Design And Manufacture Aerosonde BASED On Multirotor ( Quadqopter )," J. Meteorol. Klimatologi dan Instrumentasi, 2015.

[12] N. Nugroho and S. Agustina, "Perancangan Setting Rele Proteksi Arus Lebih Pada Motor 
Listrik Industri," Peranc. Setting Rele Prot. Arus Lebih Pada Mot. List. Ind., vol. 15, no. 1, pp. 4046, 2013, doi: 10.12777/transmisi.15.1.40-46.

[13] T. A. S, S. Widodo, and M. Kom, "Pengendalian Robot Mobile Berbasis Web Dan Internet Protocol Melalui Jaringan Wifi," J. TELE, vol. 13 , pp. 1-8, 2015.

[14] S. J. Sokop, D. J. Mamahit, M. Eng, and S. R. U. A. Sompie, "Trainer Periferal Antarmuka Berbasis Mikrokontroler Arduino Uno," EJournal Tek. Elektro Dan Komput., vol. 5, no. 3, pp. 13-23, 2016, doi:10.35793/jtek.5.3.2016.11999.

[15] W. Caesar, "PEMILIHAN KOMPONEN ELEKTRONIK (MOTOR, BATERAI, ESC) PESAWAT AEROMODELLING," 2016. [Online].Available:

http://aeroengineering.co.id/2016/02/pemilihankomponen-elektronik-motor-baterai-esc-pesawataeromodelling/. 